\title{
Tarihi Bir Yığma Minarenin Onarım Sonrasındaki Dinamik Karakteristiklerinin Deneysel Olarak Belirlenmesi
}

\author{
Experimental Determination of the Dynamic Characteristics of a Historical Masonry \\ Minaret after Repairing
}

Murat GÜNAYDIN*

Gümüşhane Üniversitesi, Mühendislik ve Doğa Bilimleri Fakültesi, Inş̧aat Mühendisliği Bölümü, 29100, Gümüşhane

• Geliș tarihi / Received: 18.01.2018 • • Düzeltilerek geliș tarihi / Received in revised form: 10.05.2018 • Kabul tarihi / Accepted: 14.05 .2018

$\ddot{O} z$

Tarihi yapılar ülkemizin önemli kültür miraslarıdır. Bu yapılar; gerek geçmişi günümüze bağlamaları, gerek yapım tekniklerindeki yüksek mühendislik bilgisi, gerekse de bulundukları bölgelere sağladıkları ekonomik katkılardan dolayı oldukça önemli olup geleceğe bozulmadan aktarılmaları kaçınılmaz bir zorunluluktur. Bu yapıların varlıklarını sürdürebilmesi, yapısal davranışlarının belirlenmesi ve gerekli onarım ve/veya güçlendirme işlemlerin uygulanmasıyla mümkündür. Bu amaçla ülkemizdeki birçok tarihi yapı onarılmış ya da güçlendirilmiştir. Uygulanan onarım ve/veya güçlendirme işlemin yapının yapısal davranışına etkisi, yapının bu işlemlerden sonraki özgün halinin korunması kadar önemlidir. Dolayısıyla, uygulanan onarım ve/veya güçlendirme işleminin yapısal davranışına olan etkisi ayrıca incelenmelidir. Bu çalı̧̧mada, Trabzon İskenderpaşa Camii minaresinin onarım sonrasındaki dinamik karakteristikleri deneysel olarak belirlenmiştir. Dinamik karakteristiklerin elde edilmesinde Deneysel Modal Analiz Yöntemi kullanılmıştır. Elde edilen dinamik karakteristikler minarenin literatürde var olan onarım öncesi sonuçları ile karşılaştırılmış ve olası farklılıklar irdelenmiştir.

Anahtar kelimeler: Çevresel titreşim yöntemi, Dinamik karakteristikler, Tarihi yığma minare

\begin{abstract}
Historical structures are substantial cultural heritage of our country. These structures are very important due to connecting the past into the present, high engineering knowledge in construction techniques and economic contribution to the regions where they are located and thus transferring these structures to the future is an inevitable necessity without distortion. The survival of these structures depends on the determination of structural behavior and implementation of required repairing and/or strengthening applications. To this end, in our country, many historical structures have been repaired or strengthened. The effect of the repairing and/or strengthening implementation is as significant as the protection of original state after these applications. The effect of the repairing and strengthening on the structural behavior therefore should be examined separately. In this study, the dynamic characteristics of the Trabzon Iskenderpaşa mosque minaret are identified experimentally after the repairing. The Experimental Modal Analysis Method is used to identify dynamic characteristics. The obtained results are compared with the pre-repair results of the minaret in the literature and the possible differences are examined.
\end{abstract}

Keywords: Dynamic characteristics, Historical masonry minaret, Operational Modal Analysis

* Murat GÜNAYDIN; mgunaydin@gumushane.edu.tr; Tel: (0456) 2331000 (dahili: 1644); orcid.org/0000-0002-8549-2985 


\section{Giriş}

Tarih boyunca birçok medeniyete ev sahipliği yapan ülkemiz, farklı yüzyıllarda inşa edilmiş çokça kültür mirası yapısına (cami ve minareler, hanlar, köprüler, saraylar, su kemerleri vesaire) sahiptir. Bu mirasın özgün niteliklerini bozmadan gelecek nesillere güvenle aktarılması; bilinçli bir toplumun yanında, bu yapıların yapisal davranışların doğru bir şekilde belirlenmesi ve gerekli onarım ve/veya güçlendirme işlemlerin uygulanmasıyla mümkündür.

Tarihi yapılar; inşa edildiği çağın malzeme özelliklerini, yapım tekniklerini ve mimari / mühendislik öğelerini günümüze taşıyan yapılardır. Zaman içerisinde bu yapılar; deprem, yangın, yağmalama, zeminde oturma, malzeme dayanım kayıpları ve çevresel etikler gibi sayısız olumsuz etkiye maruz kalabilmektedir. Bu etkiler neticesinde; bazıları yıkılmakta, bazıları ağır hasar almakta bazıları ise hasar almayı ayakta kalabilmektedir. Gerek hasar almış gerekse de almamış olanların yapısal davranışları titizlikle belirlenmeli, ihtiyacı olanlar onarılmalı veya güçlendirilerek gelecek nesillere aktarılmalıdır.

Tarihi yapılarımızın önemli bir kısmını oluşturan yı ğma minareler; narin yapılarından dolayı özellikle deprem ve rüzgâr gibi dinamik etkiler altında hasara uğrayabilmekte, hatta yıkılabilmektedirler (Şekil 1). Dolayısıyla bu yapıların olası dinamik etkilere karşı gösterecekleri yapısal davranışlarının belirlenmesi ve gerekli onarım / güçlendirme önlemlerin alınması gerekmektedir. Ayrıca onarılmış ve/veya güçlendirilmiş minarelerin dinamik davranışlarındaki değişimler, gerek onarım / güçlendirme öncesi ve sonrasında gerekse de deprem öncesi ve sonrasinda belirlenmeli, hatta periyodik olarak da takip edilmelidir.

Yapıların dinamik davranışları doğal frekans, mod şekli ve sönüm oranı olarak tanımlanan dinamik karakteristiklere bağlı olarak analitik ve deneysel yöntemlerle belirlenmektedir. Analitik yöntemde yap1 geometrisi, malzeme özellikleri ve sinır şartlarına göre sonlu eleman modelleri oluşturulur, gerçekleştirilen serbest titreşim (modal) analizleri sonucunda doğal frekanslar ve mod şekilleri elde edilir. Analitik dinamik karakteristikler yapının mevcut durumunu bazı durumlara tam olarak yansıtmayabilir. Çünkü sonlu eleman modellerinde dikkate alınan parametreler; yap1 malzemelerinin zamanla dayanımını yitirmesi, yapının inşası sırasında gerçekleşen işçilik hataları, yapının maruz kaldığı farklı yüklemeler sonucu oluşan çatlamalar, yorulmalar, mesnet çökmeleri, sıcaklık etkileri gibi nedenlerden dolay1 değişime uğrayabilmekte ve zaman içerisinde hedeflenen değerlerinden uzaklaşabilmektedir. Özellikle tarihi yapılar gibi belirsizliklerin fazla olduğu sistemlerde; analitik olarak belirlenen dinamik karakteristiklerin, yapıların dinamik davranışlarının belirlenmesinde kullanılması yanlış sonuçların elde edilmesine neden olabilir. Yapı dinamik karakteristikleri, analitik yöntemlerin yanında deneysel yöntemlerle de belirlenebilmektedir. Deneysel yöntemler doğrudan yap1 üzerine uygulandığından, elde edilen dinamik karakteristikler yapının o andaki mevcut durumunu yansitmakta ve doğruluğu daha kesin olabilmektedir.

Yapıların dinamik karakteristikleri deneysel olarak "Deneysel Modal Analiz Yöntemi" yardımıyla belirlenebilmektedir. $\mathrm{Bu}$ yöntemde, yap1 üzerinde bazı noktalara hassas ivmeölçerler yerleştirilmekte ve ivmeölçerlerden alınan titreşim sinyalleri veri toplama ünitesi yardımıyla toplanmaktadır. Toplanan sinyaller, yazılımlar vasıtasıyla bazı işlemlerden geçirildikten sonra dinamik karakteristikler elde edilmektedir. Deneysel Modal Analiz yöntemi; Zorlanmış Titreşim Yöntemi ve Çevresel Titreşim Yöntemi olmak üzere ikiye ayrılmaktadır. Zorlanmış Titreşim Yöntemi'nde, yapı bilinen ve ölçülebilen bir etki ile (sarma tablası, darbe çekici, sarsıcılar vd.) titreştirilmekte ve yapının bu etkiye verdiği tepki ölçülmektedir. Çevresel Titreşim Yöntemi'nde ise yapının çevresel bir etki ile (rüzgâr, taşı yükü, deprem, patlatma veya yaya hareketi gibi) titreştiği kabul edilmekte ve yapının bu etkiye göstermiş olduğu tepki ölçülmektedir. Tepkilerin ölçülüp değerlendirilmesinde frekans ve zaman ortamına dayalı birçok yöntem yaygın olarak kullanılmaktadır. Kullanılan yöntemlerin matematik tabanları aynı olmakla birlikte veri işleme, denklem çözme teknikleri ve matris dizilişleri birbirinden farklıdır (Altunışık, 2010; Sevim, 2010; Günaydın, 2016).

Son y1llarda oldukça popüler olan Deneysel Modal Analiz Yöntemi ile birlikte özellikle tarihi yapıların yapısal davranışları hasarsız bir şekilde elde edilebilmekte, hasar tespiti yapilabilmekte ve yap1 sağlığı zamanla izlenebilmektedir. Gentile ve Saisi (2007) $74 \mathrm{~m}$ yüksekliğindeki tarihi bir çan kulesinin yapısal durum değerlendirmesini yapmışlardır. $\mathrm{Bu}$ amaçla yapının dinamik karakteristikleri çevresel titreşim testi yöntemiyle elde edilmiş, yapının sonlu eleman modeli oluşturulmuş ve bu model elde edilen deneysel sonuçlara göre iyileştirilmiştir. 


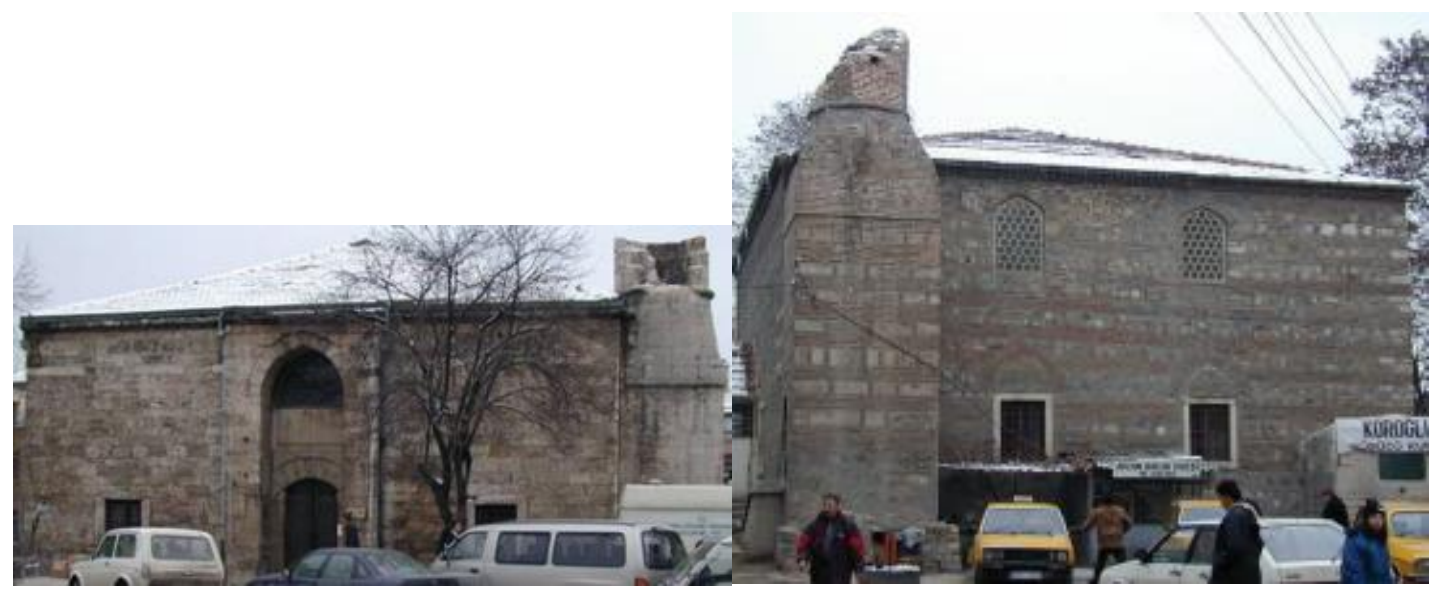

a) Deprem sonrası yıkılan bazı tarihi yığma minareler (Doğangün ve Sezen, 2012).

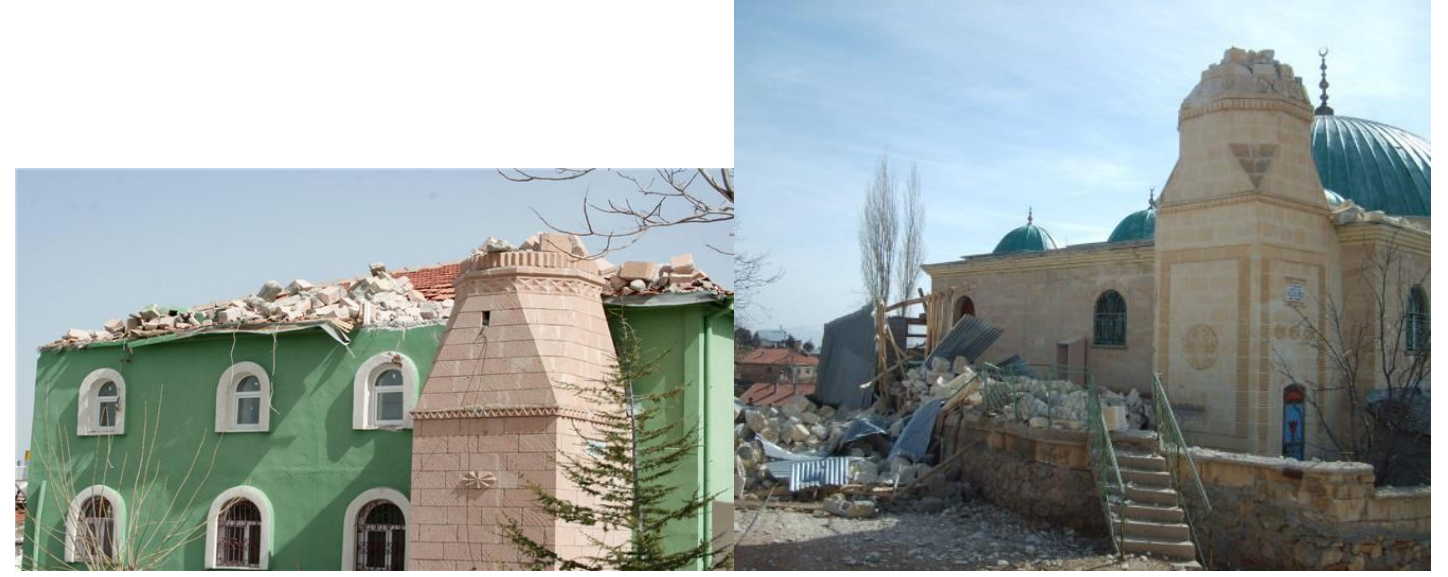

b) Şiddetli rüzgâr sonrası yıkılan bazı tarihi yığma minareler (URL 1 ve 2, 2018).

Şekil 1. Dinamik etkiler neticesinde yıkılmış bazı yığma minareler.

Ivorra ve Pallares (2007) 15.yy da inşa edilmiş Santa Justa y Rufina çan kulesinin modal davranışının belirlenmesi üzerine çalışmışlardır. Çalı̧̧mada deneysel dinamik karakteristikler deneysel ölçümlerle belirlenmiştir. Bu amaçla dört ivmeölçer yapı üzerine bağlanarak çevresel titreşim sinyalleri toplanmıştır. Yapının ilk beş modu $0-10 \mathrm{~Hz}$ arasında elde edilmiştir. Yapının sonlu eleman modeli ayrıca oluşturulmuş ve elde edilen deneysel verilere göre iyileştirilmiştir. Brencich ve Sabia (2008) 1866'da inşa edilmiş 18 açıklıklı tarihi Tanaro Köprüsünün yapısal davranışının belirlenmesi üzerine deneysel ve analitik çalışmalar gerçekleştirmişlerdir. Köprünün dinamik karakteristikleri servis yükleri altında çevresel titreşim testi yöntemiyle belirlenmiştir. Ramos vd. (2010) Portekiz'de bulunan tarihi bir saat kulesi ve tarihi bir kilisenin yapısal davranışlarını deneysel modal analiz yöntemi ile belirlemişlerdir. Çalışmada, yapıların hasar durumlarının incelenmesi, hasar durumlarının titreşim sinyalleri kullanarak önceden tahmin edilmesi ve yapıların yap1 sağlıkları izlenerek korunması konularında deneysel ve analitik çalışmalar yapılmıştır.
Atamturktur ve Laman (2012) tarihi anitsal yapıların yapısal durumların değerlendirilmesi koşunda son y1llarda meydana gelen gelişmeleri inceleyen bir çalışma gerçekleştirmişlerdir. Livaoğlu vd. (2015) 15.yy da inşa edilen tarihi Hoca Tabip Camii minaresinin dinamik karakteristiklerini deneysel modal analiz yöntemiyle belirlemişlerdir. Elde edilen dinamik karakteristikler minarenin sonlu eleman modelinin iyileştirilmesinde kullanılmış ve sonlu eleman modelinin yapının yapısal davranışının elde edilmesinde kullanılabileceği belirtilmiştir. Lourenço ve Ramos (2011) tarihi yapıların dinamik davranışların belirlenmesi ve izlenmesi konusunda çalışmışlardır. Çalışmada; titreşim verileriyle tarihi yapılarda oluşabilecek hasarların önceden belirlenebilmesi, tarihi yapıların yap1 sağlıkların izlenebilmesi ve geleneksel kablolu veri toplama üniteleri ile kablosuz veri toplama ünitelerinden elde edilen deneysel sonuçların karşılaştııılması konularında irdelemeler yapmışlardır. Saisi vd. (2015) 13.yy da inşa edilmiş $54 \mathrm{~m}$ yüksekliğindeki Gabbia kulesinin yapısal durum değerlendirilmesi üzerine çalışmışlardır. Çalışma Mayıs 2012'de İtalya'da 
meydana gelen deprem sonrasinda gerçekleştirilmiştir. Yapı dinamik karakteristikleri sekiz ay boyunca çevresel titreşim testi yöntemiyle izlenmiştir. Yapı doğal frekansların değişen sıcaklık değerlerinde $\left(-2{ }^{\circ} \mathrm{C}-45^{\circ} \mathrm{C}\right) \% 5-11$ arasında değiştiği ve bu değerlerin yapının sonlu eleman modelinin iyileştirilmesinde kullanılabileceği vurgulanmıştır. Türker (2014) yedi açıklıklı tarihi Aspendos köprüsünün yapısal davranışını belirlemiştir. Bu kapsamda köprünün dinamik karakteristikleri çevresel titreşim testi yöntemiyle belirlenmiştir. Köprünün başlangıç sonlu eleman modeli oluşturulmuş ve deneysel sonuçlara göre iyileştirilmiştir. Daha sonra köprünün iyileştirilmiş sonlu eleman modeli kullanılarak statik ve dinamik analizleri gerçekleştirilmiştir. Altunışı vd. (2016) tarihi Trabzon kalesinin yapısal davranışını deneysel ve analitik yöntemlerle belirlemişlerdir. Yap1 dinamik karakteristikleri deneysel modal analiz yöntemiyle belirlenmiş, deneysel ve analitik frekanslar arasında \%26 oranında bir farkın elde edildiği belirtilmiş ve bu farkın yapı sonlu eleman modelinin iyileştirilmesiyle azaltılması gerektiği vurgulanmıştır. Çalışmada yapının deprem davranışı ayrıca belirlenmiştir. Çalık (2017) farklı taşıyıcı sistemli tarihi cami ve minarelerin deneysel dinamik karakteristikleri belirlemek amacıyla deneysel modal analiz yöntemi kullanmıştır. Restorasyon öncesi ve sonrasında elde edilen veriler irdelenerek tarihi yapilar üzerinde gerçekleştirilen restorasyon etkilerini ayrıca irdelemiştir. Çalışmada, tarihi cami ve minarelerin analitik doğal frekanslarının deneysel yöntemlere dayalı geliştirilen formülasyonlar ile yaklaşı olarak elde edilebileceği, sönüm oranı ve modal davranışlarının tahmin edilebileceği ve restorasyon uygulamalarının yapıların dinamik karakteristiklerine önemli derecede etkisinin olduğu ifade edilmiştir. Torres vd. (2017) tarihi Santiago Metropolitan Katedrali'nin dinamik karakteristiklerini deneysel modal analiz yöntemiyle belirlemiş ve elde edilen sonuçları yapının sonlu eleman modelinin iyileştirilmesinde kullanmışlardır. Çalışma sonucunda iyileştirilmiş sonlu eleman modelinin yapının mevcut durumunun değerlendirilmesinde kullanılabileceği vurgulanmıştır.

$\mathrm{Bu}$ çalışmada, Trabzon il merkezinde bulunan tarihi İskenderpaşa camii minaresinin onarımı sonrasında dinamik davranışı deneysel olarak belirlenmiştir. Yap1 dinamik davranışını temsil eden dinamik karakteristiklerinin (doğal frekanslar, mod şekilleri ve sönüm oranları) elde edilmesinde Çevresel Titreşim Yöntemi kullanıl- mıştır. Elde edilen dinamik karakteristikler minarenin literatürde var olan onarım öncesi sonuçları ile karşılaştırılmış ve olası farklılıklar irdelenmiştir.

\section{Deneysel Yöntem}

\section{1. Çevresel Titreşim Yöntemi}

Çevresel Titreşim Yöntemi yapılarda rüzgâr, deprem, taşıt yükleri, yaya hareketleri ve darbe etkileri gibi çevresel etkilerden meydana gelen titreşimleri dikkate alarak yapı dinamik karakteristikleri deneysel olarak belirlenmesinde kullanılan bir yöntemdir. Yapılara etkiyen titreşimlerin genliği ve zamanla değişimi bu yöntem için bilinememektedir. Dolayısıyla Etki Davranış Fonksiyonu belirlenememektedir (Zhang vd., 2002; Brincker vd., 2003). Dinamik karakteristikler, titreşimlerin yap1 üzerinde oluşturdukları tepki verilerinin zaman veya frekans tanım alanlarında işlenmesi sonucu elde edilen Tepki Davranış Fonksiyonu ile belirlenmektedir. Davranış Fonksiyonunun belirlenmesinde zaman veya frekans ortamında gerçekleştirilen işlemelerin birbirlerine göre bir üstünlüğü bulunmayıp her iki ortama dayalı yöntemler dinamik karakteristiklerin elde edilmesinde kullanılabilir. Zaman ve frekans ortamına dayalı pek çok yöntem literatürde bulunmaktadır. Bu yöntemlerin bazıları Şekil 2'de, Çevresel Titreşim Yöntemine göre yap1 dinamik karakteristiklerinin elde edilmesine ait temsili akış şeması ise Şekil 3'te verilmektedir (Altunışık, 2010; Sevim, 2010; Günaydın, 2016).

Minareye ait dinamik karakteristiklerinin belirlenmesinde literatürde sıklıkla tercih edilen, Geliştirilmiş Frekans Ortamında Ayrıştırma (GFOA) ve Stokastik Altalan Belirleme (SAB) yöntemleri kullanılmıştır. Bu yöntemlere ait temel denklemler aşağıda verilmiş olup ilgili yöntemlere ait denklemlerin kapsamlı teorisi literatürde verilmiştir (Brincker vd., 2003).

GFOA yönteminde, bir titreşim pikinin etrafında tanımlanan tek serbestlik dereceli Güç Spektral Yoğunluk fonksiyonu, Ters Ayrık Fourier Dönüşümü kullanılarak zaman ortamına geri dönüştürülebilmektedir. Doğal frekans, zamana bağlı sıfır geçiş sayısının belirlenmesiyle; sönüm ise tek serbestlik dereceli normalize edilmiş oto korelasyon fonksiyonunun logaritmik azalışıyla elde edilmektedir (Felber, 1993; Peeters, 2000; Rainieri vd., 2007; Altunışık, 2010; Sevim, 2010; Günaydın, 2016). 


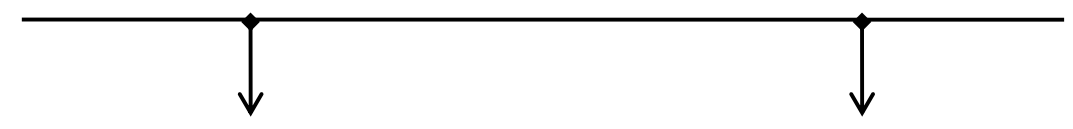

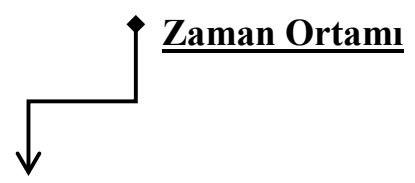

Yöntem

Ratgele Azaltım

$\checkmark$ Tekrarlanan

$\checkmark$ Maksimum Olasılik

$\checkmark$ Stokastik Altalan Belirleme (SAB)

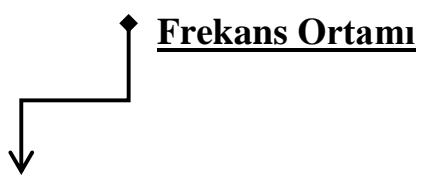

Yöntem

$\checkmark$ Piklerin Seçilmesi (PS)

$\checkmark$ Frekans Ortamında Ayrıştırma (FOA)

$\checkmark$ Geliştirilmiş Frekans Ortamında Ayrıştırma (GFOA)

$\checkmark$ Polimax

Şekil 2. Çevresel Titreşim Yöntemine göre dinamik karakteristiklerin belirlenmesinde kullanılan bazı yöntemleri.

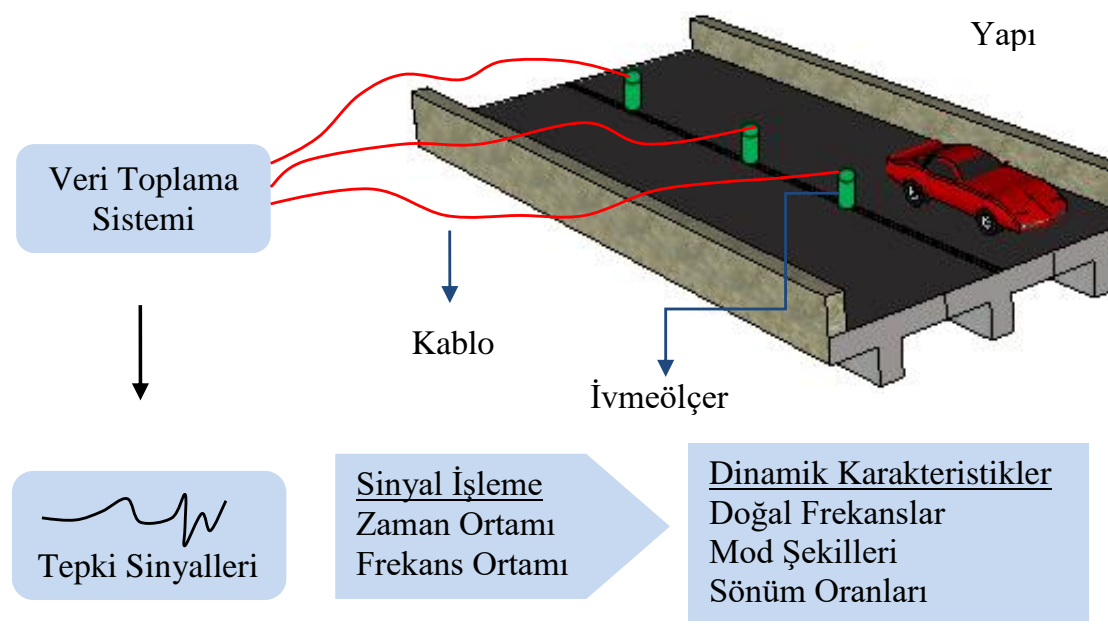

Şekil 3. Çevresel Titreşim Yöntemine göre yapı dinamik karakteristiklerinin belirlenmesi.

GFOA yönteminde ölçülmeyen etki kuvveti ve ölçülen davranış fonksiyonu arasındaki ilişki;

$$
\mathbf{G}_{\mathbf{y y}}(\mathrm{jw})=\mathbf{H}(\mathrm{jw})^{*} \mathbf{G}_{\mathbf{x x}}(\mathrm{jw}) \mathbf{H}(\mathrm{jw})^{\mathrm{T}}
$$

şeklinde ifade edilmektedir (Bendat ve Piersol, 2004). Eşitlik 1'de; $\mathbf{G}_{\mathbf{x x}}$ (jw) etki sinyalinin Güç Spektral Yoğunluk fonksiyonunu, $\mathbf{G}_{\mathbf{y y}}$ (jw) tepki sinyalinin Güç Spektral Yoğunluk fonksiyonunu ve $\mathbf{H}(\mathrm{jw})$ frekans davranış fonksiyonunu göstermektedir.

Stokastik Altalan Belirleme (SAB) yöntemi korelasyon veya spektruma ihtiyaç duymadan doğrudan zaman verileriyle çalışan, zaman ortamına dayalı bir yöntemdir. $\mathrm{Bu}$ yöntem dinamik karakteristiklerin belirlenmesi için çok uygundur (Peeters ve Roeck, 2000; Peeters, 2000; Yu ve Ren, 2005). Bu yöntemde yap1 sisteminin dinamik davranışı lineer, sabit katsayılı ikinci derece diferansiyel denklem olarak,

$$
\mathbf{M U ̈}(\mathrm{t})+\mathbf{C} \dot{\mathbf{U}}(\mathrm{t})+\mathbf{K U}(\mathrm{t})=\mathbf{R}(\mathrm{t})=\mathbf{B u}(\mathrm{t})
$$

şeklinde ifade edilmektedir. Burada; $\mathbf{M}, \mathbf{C}, \mathbf{K}$ sirasıyla sistemin kütle, sönüm ve rijitlik matrisleridir. $\mathbf{R}(\mathrm{t})$ titreşim kuvvetini; $\mathbf{U}(\mathrm{t})$, $\dot{\mathbf{U}}(\mathrm{t}), \ddot{\mathbf{U}}(\mathrm{t})$ ise zamana bağlı yer değiştirme, hız ve ivme vektörlerini göstermektedir. Burada $\mathbf{R}(\mathrm{t})$ kuvvet vektörü, ortamdaki verileri 
simgeleyen $\mathbf{B}$ matrisi ve $\mathbf{u}(\mathrm{t})$ vektörü cinsinden ifade edilebilmektedir (Altunışık, 2010; Sevim, 2010; Günaydın, 2016).

Yapıların deneysel yöntemler ile elde edilen mod şekillerinin doğruluğu sadece frekans değerleri arasındaki farklara bakılarak değerlendirilmemektedir. Deneysel olarak elde edilen mod şekilleri arasında tanımlanan Modal Güvence Kriteri (MGK), deneysel mod şekilleri arasındaki uyumu ifade etmektedir. MGK, deneysel olarak hesaplanan farklı mod şekil vektörlerinin karşıllaştırılmasında ya da bir yöntem kullanılarak hesaplanan mod şekil grubunun doğruluğunun kontrol edilmesinde kullanılmaktadır. İki mod şekli arasındaki Modal Güvence Kriteri,

$$
\operatorname{MGK}\left(\boldsymbol{\psi}_{\mathrm{a}}, \boldsymbol{\psi}_{\mathrm{d}}\right)=\frac{\left|\boldsymbol{\psi}_{\mathrm{a}}^{\mathrm{T}} \boldsymbol{\psi}_{\mathrm{d}}\right|^{2}}{\left(\boldsymbol{\psi}_{\mathrm{a}}^{\mathrm{T}} \boldsymbol{\psi}_{\mathrm{a}}\right)\left(\boldsymbol{\psi}_{\mathrm{d}}^{\mathrm{T}} \boldsymbol{\psi}_{\mathrm{d}}\right)}
$$

şeklinde ifade edilmektedir (Allemang, 2003; Sevim, 2010; Günaydın, 2016). Burada; $\boldsymbol{\Psi}_{\mathrm{a}}$ ve

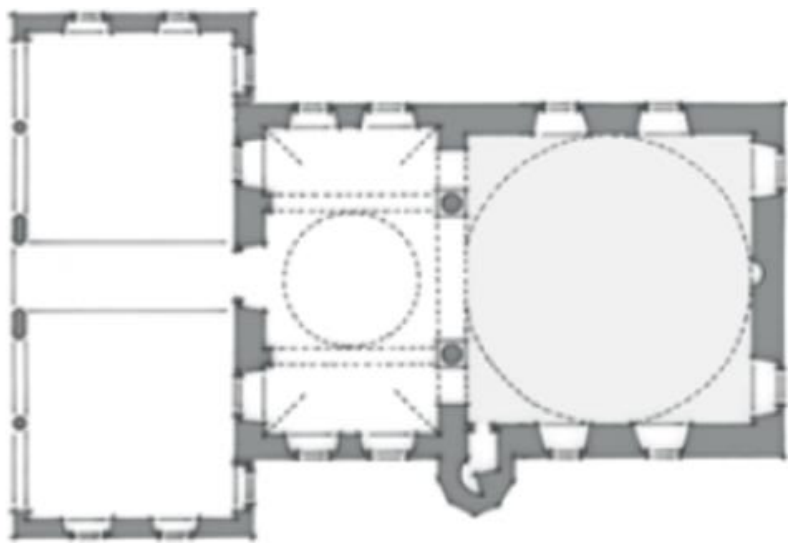

$\boldsymbol{\psi}_{\mathrm{d}}$ deneysel mod şekil vektörlerini göstermektedir. Eğer $\boldsymbol{\psi}_{\mathrm{a}}$ ve $\boldsymbol{\psi}_{\mathrm{d}}$ aynı mod şekil vektörleri iseler, MGK birim matris olmalıdır. Eğer $\boldsymbol{\psi}_{\mathrm{a}}$ ve $\boldsymbol{\psi}_{\mathrm{d}}$ farklı mod şekil vektörleri iseler, MGK değeri sıfıra yakın olmalıdır.

\section{Deneysel Çalışma}

\subsection{Trabzon İskenderpaşa Camii}

Trabzon İskenderpaşa Camii; 1529 yılında, Kanuni Sultan Süleyman'ın Padişahlığ zamanında Vali İskender Paşa tarafindan inşa ettirilmiştir. Eser, dikdörtgen bir iç hacim ile buna yatay olarak birleşen dikdörtgen biçimli son cemaat revakından oluşmaktadır. Ana mekan; geniş bir kubbe ve bunun kuzeyinde bulunan küçük bir kubbe ile her iki yanında yarım kubbemsi tonozların oturduğu iki bölümden oluşmaktadır. $\mathrm{Bu}$ bölümleri birbirlerine geniş açıklıklı, duvarlara ise küçük açıklıkla kemerlerle bağl1 iki sütün birbirinden ayırır (Tuluk, 2007). Cami minaresi iç mekan batı duvarına bitişik olup küçük bir kapı ile içine girilmektedir. Cami planı ve mevcut hali Şekil 4'te verilmektedir.

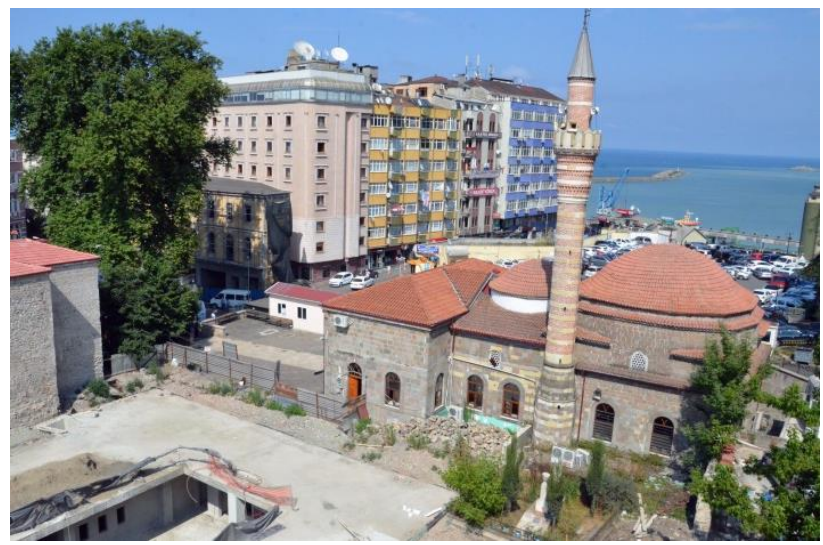

Şekil 4. Trabzon İskenderpaşa Camii planı ve genel görünümü (Tuluk, 2007; URL-3, 2018).

Camii minaresi tek şerefeli olup inșasında taș ve tuğla kullanılmıştır. Klasik Osmanlı mimarisini yansitan minare; temel üzerine oturan kaide, küp, gövde, şerefe, petek, külah ve alem gibi bölümlerden oluşmaktadır. Küp ve kaide kısmı taştan, gövde ve petek kısmı tuğladan, külah kısmı ise ahşap üzerine kurşun kaplamadan yapılmıştır. Şerefe atında tuğladan yapılmış süslemeler vardır. Şerefe korkulukları taştan olup üzerleri motiflerle süslenmiştir. Şekil 5'te minarenin görünümü bölümleri ve bazı geometrik ölçülerine bilgiler verilmiştir.
Minare toplam boyu $20.5 \mathrm{~m}$ dir. Minare iç kısmında $0.2 \mathrm{~m}$ çapında taş bir sütün vardır. Taş sütün etrafında $0.2 \mathrm{~m}$ basamak kalınlığına sahip şerefeye kadar devam eden merdiven bulunmaktadir.

2007 yılı sonunda Vakıflar Genel Müdürlüğü tarafindan Trabzon İskenderpaşa Camii Minaresinin restorasyonu amaciyla bazı onarım işlemleri gerçekleştirilmiştir. Onarım işlemlerine ait bazı aşamalar aşağıda verilmiştir. 


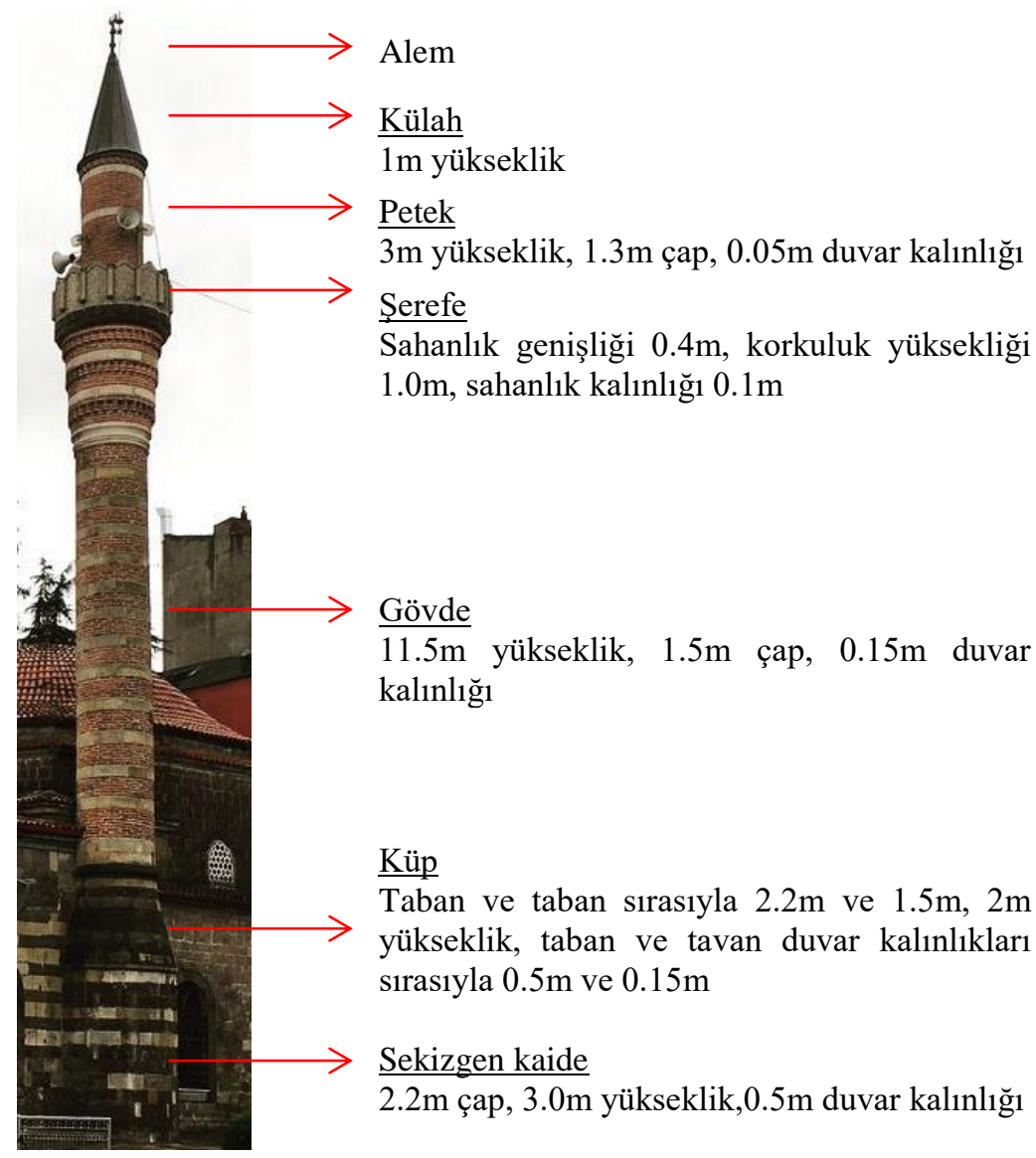

Şekil 5. Trabzon İskenderpaşa Camii minaresi görünümü, bölümleri ve bazı geometrik özellikleri.

- Ahşap külah üzerindeki kurşun örtü kaldırılmış, külah, seren ve gergiler sökülmüştür. Şerefe altı, şerefe ve petek kısmının özgün halinin korunarak yeniden yapılmasının ardından ahşap külah imalatı, seren ve gergiler hazırlanan projeye göre yenilenmiştir. Ahşap külah üzerine $2 \mathrm{~mm}$ kalınlığında membran serilmiş ve üzerine $1.5 \mathrm{~mm}$ kalınlığında kurşun ile örtülmüştür. Ayrıca sökülen alem yüzey temizliği yapıldıktan sonra yerine takılmıştır.

- Minare peteği ve şerefesi sökülmüş, kullanılabilecek sağlam taşları tespit edilmiş ve 1slah edildikten sonra özgün hali korunarak yeniden inşa edilmiştir. Ayrıca yeniden inşa edilen şerefe ve petek kısımlarında horosan harcı ile derzler teşkil edilmiştir.

- Şerefe korkulukları özenle sökülmüş, kullanılabilecek sağlam taşları tespit edilmiş ve sslah edildikten sonra özgün hali korunarak yeniden inşa edilmiştir. Şerefe altında ve petek üzerindeki kirpi motif imalatları yapılmıştır.

- Sökülen merdiven basamakları özgün hali korunarak yenilenmiştir.
- Kaide ve küp kısmın birleştiği yerdeki taş korniş özgün hali korunarak yenilenmiştir.

- Minare gövdesindeki yonu taşı yüzeylerde ince dişli el tarağı ile, tuğla yüzeylerde ise tel firça ile temizlik yapılmıştır. Gövdedeki tuğla ve yonu taşı yapı elemanları arasındaki derzler açılmış ve horasan harciyla yeniden doldurulmuştur.

- Minarede değişmesi gereken taş ve tuğlalar özenle çürütülmüş, bazıları kaplanmış bazıları ise yenilenmiştir.

Minarenin onarım öncesi ve sonrasına ait bazı resimler sırasıyla Şekil 6'da verilmiştir.

İskenderpaşa Camii merkezi konumuyla yoğun bir kullanıma cevap vermektedir. Geniş bir avlusu olmasına rağmen özellikle Cuma günleri bu avlu yetersiz kalabilmektedir. Caminin tarihi dokusunun ortaya çıkarılması, mevcut avlunun büyütülmesi, avlu altına yeni bir abdesthane ve mescit kazandırılması amaciyla, caminin minare yönünde bulunan avlusunda Trabzon Belediyesi tarafından yenileme çalışmaları yapılmıştır. 

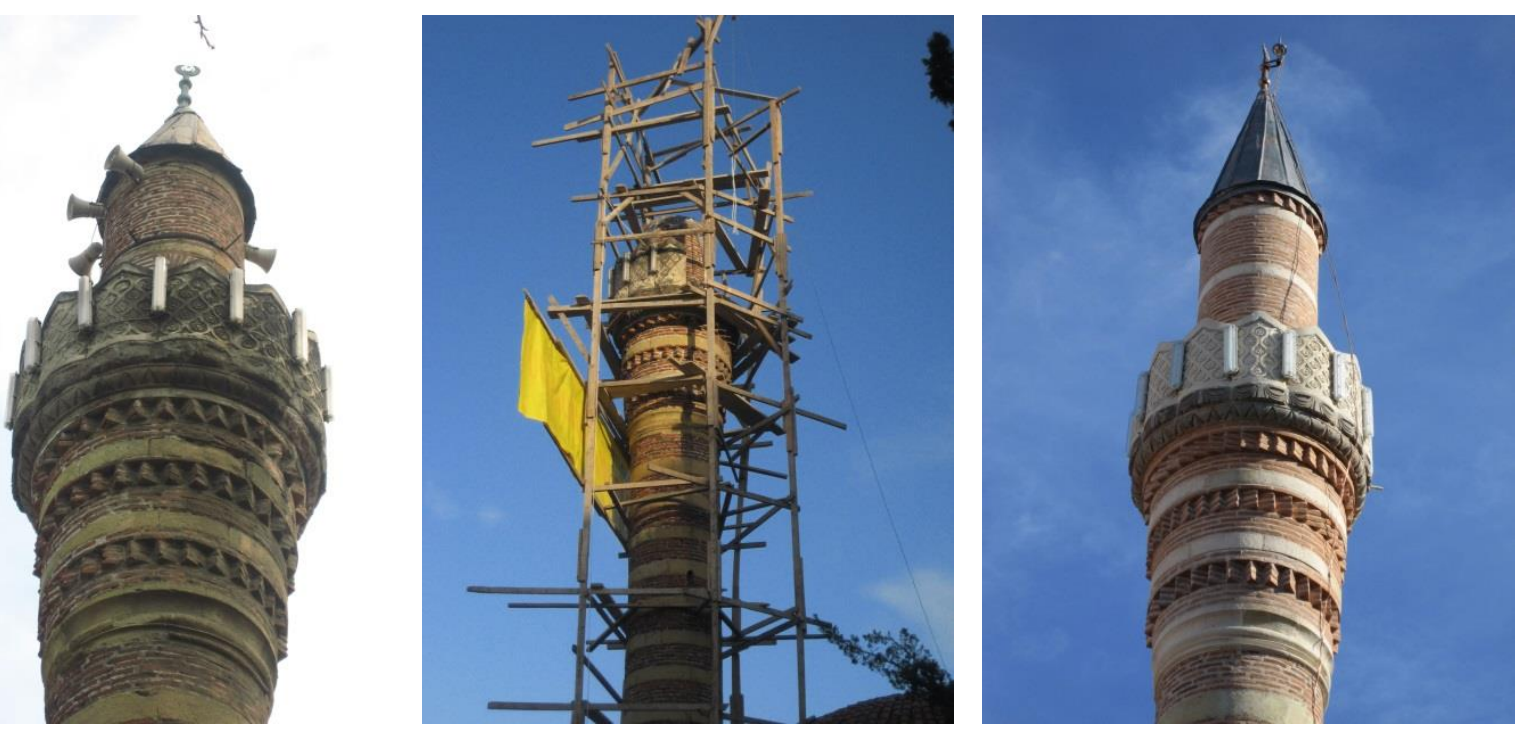

Şekil 6. Trabzon İskenderpaşa Camii minaresinin onarım öncesi ve sonrasına ait bazı resimler.

$\mathrm{Bu}$ amaçla, cami avlusuna bitişik eklentiler kaldırılmış, abdesthane ve mescit inşası için avlu kazılmış ve ilgili birimler inşa edilmiştir (Şekil 7). Şekil 7'de görüleceği üzere kazısı yapılan alan minareye oldukça yakındır. Gerekli önlemlerinin alınmaması durumunda, kazı etkisiyle minarenin oturduğu zemin özelliklerinin değişebileceği dolayısıyla da minarenin mesnet koşullarının değişebileceği açıktır. Mesnet koşullarında oluşacak bir değişim doğrudan yapı dinamik karakteristiklerini, yani yapı dinamik davranışını etkilemektedir. Dolayisıyla zemin parametrelerinde değişime neden olabilecek uygulamaların öncesi ve sonrasında dinamik karakteristiklerinin belirlenmesi, yapının dinamik davranışının doğru olarak elde edilmesinde büyük öneme sahiptir.
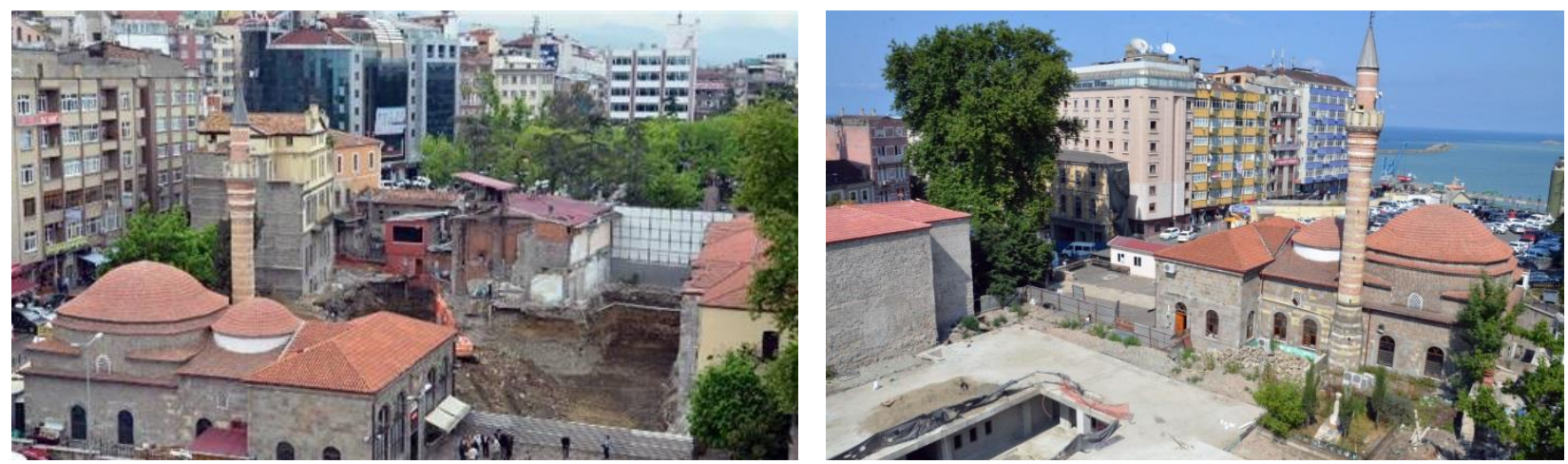

Şekil 7. Trabzon İskenderpaşa Camii avlusunda yapılan yenileme çalışması (URL-4, 2018).

\section{2. Çevresel Titreşim Yöntemiyle Minare Dinamik Karakteristiklerinin Belirlenmesi}

Çalı̧̧ma kapsamında minarenin dinamik karakteristikleri Çevresel Titreşim Yöntemi ile elde edilmiştir. Titreşim sinyallerinin toplanmasında 8 adet B\&K 8340 tipi ivmeölçer kullanılmıştır. Toplanan sinyaller 17 kanallı B\&K 3560 veri toplama ünitesinde birleştirilerek PULSE (2006) yazılımına aktarılmıştır. Bu sinyaller OMA (2006) yazılımına transfer edilerek işlenmiş ve minareye ait dinamik karakteristikler elde edilmiştir. Şekil 8'de veri toplama ünitesi ve ivmeölçere ait resimler verilmektedir.

Minarenin dinamik karakteristiklerini belirlemek amaciyla, minare içinde bulunan taş sütün üzerindeki dört farklı noktaya $\mathrm{x}$ ve y yönünde (birbirine dik olacak şekilde) toplam 8 adet tek eksenli ivmeölçer yerleştirilmiş ve minarenin çevresel etkiler altındaki titreşim verileri 10 dakika boyunca $0-25 \mathrm{~Hz}$ aralığında toplanmıştır. İvmeölçer yerleşim düzeni ve PULSE yazılımında oluşturulan temsili minare modeli Şekil 9'da verilmektedir. 

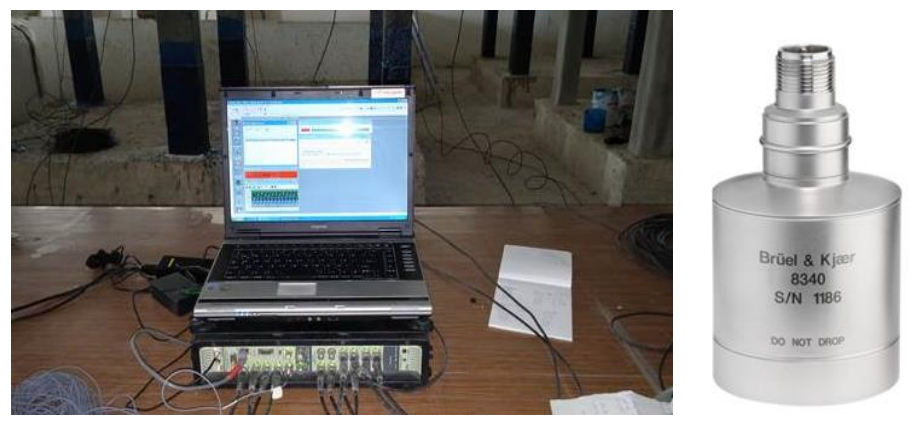

Şekil 8. Veri toplama ünitesi ve ivmeölçer.

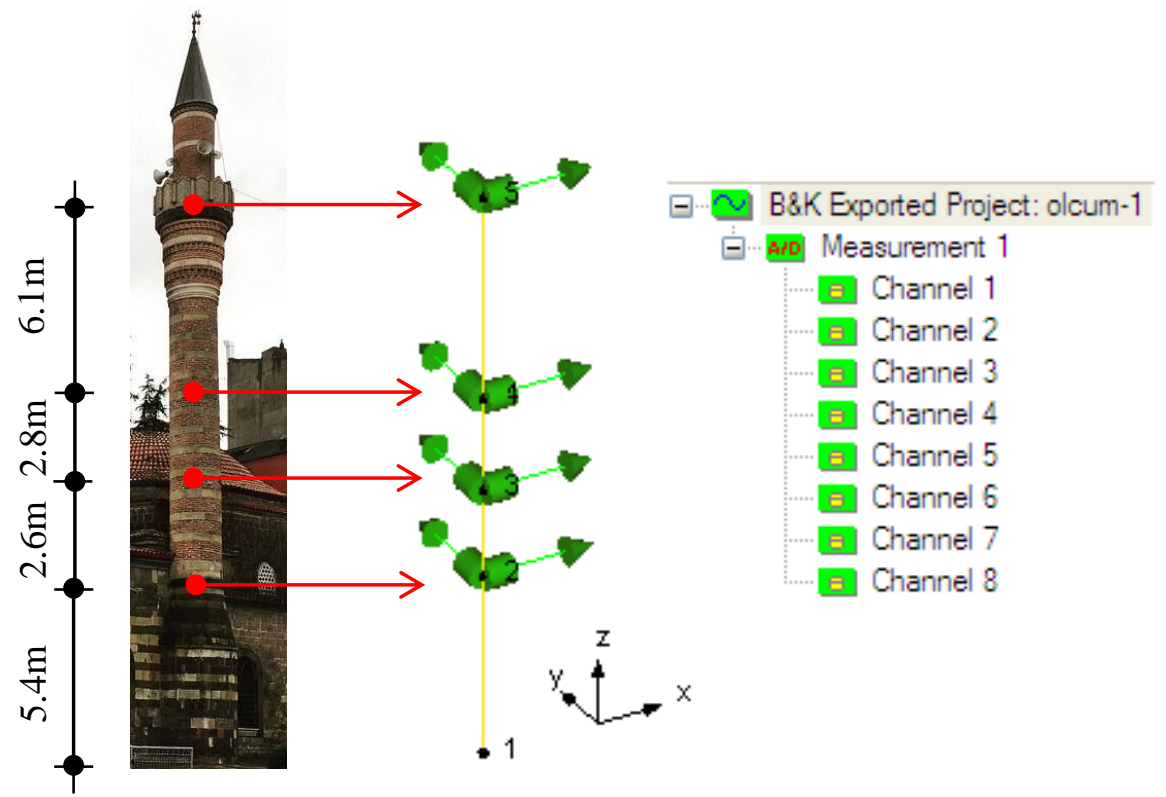

Şekil 9. İvmeölçer yerleşim planı ve PULSE yazılımında oluşturulan temsili minare modeli.

Minarenin çevresel titreşim testlerinden toplanan sinyallerin GFOA yöntemine göre ayrıştırılması sonucu elde edilen spektral yoğunluk matrislerinin tekil değerleri Şekil 10'da verilmektedir. Şekilde görülen sinyallerin pik yapan değerlerin her biri yapısal modlara karşılık gelmektedir. Bu piklerin seçilmesiyle minarenin doğal frekansları ve sönüm oranları hesaplanmaktadır. Çalışmada dinamik karakteristikler ilk yedi mod için elde edilmiștir. Minarenin GFOA yöntemine göre elde edilen dinamik karakteristikleri Şekil 11'de verilmektedir. Minarenin ilk yedi modu farkl1 salınım hareketine sahip ötelenme modu şeklinde elde edilmiştir.

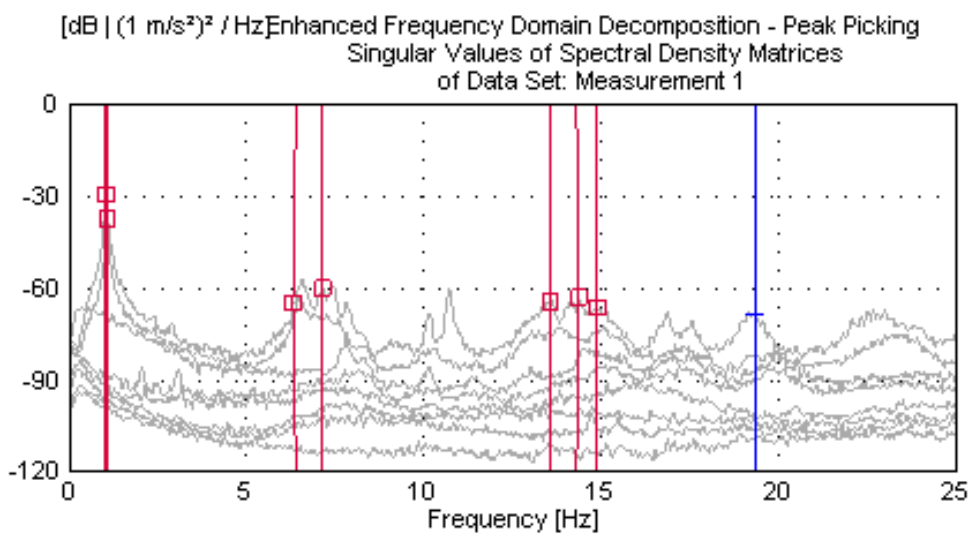

Şekil 10. Minare için elde edilen spektral yoğunluk matrislerinin tekil değerleri. 


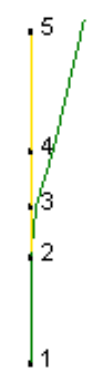

1.Mod

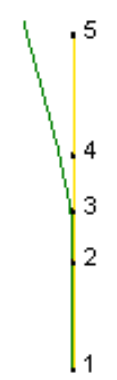

2.Mod

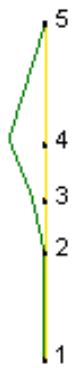

3.Mod

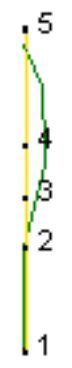

4.Mod
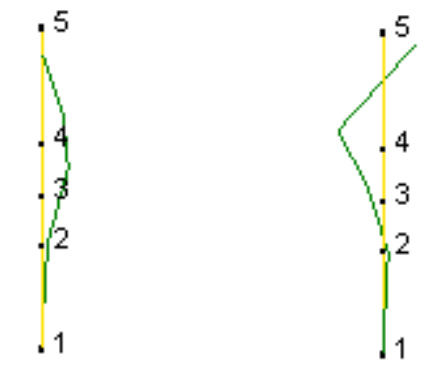

5.Mod

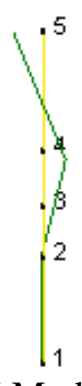

Şekil 11. Minarenin GFOA yöntemine göre elde edilen mod şekilleri.

Stokastik Altalan Belirleme (SAB) yöntemi kullanılarak minare için elde edilen stabilizasyon diyagramı ve spektral yoğunluk fonksiyonu grafikleri Şekil 12'de verilmektedir. Şekilde görülen ve genellikle sinyallerin pik yaptı̆̆ 1 noktalarda ince bir çizgi oluşturan kısımlar yapısal modlara karşılık gelmektedir. $\mathrm{Bu}$ kısımların seçilmesiyle sistemin dinamik karakteristikleri elde edilmektedir.
Minarenin için GFOA ve SAB yöntemlerinden elde edilen mod şekilleri benzerdir. Her iki yöntemden elde edilen mod şekilleri arasındaki uyumu gösteren Modal Güvence Kriteri (MGK) değerleri Tablo 1'de verilmektedir. Tablo 1'den de görülebildiği ilk yedi mod șekli için MGK değerleri 1'e yakındır. Buradan GFOA ve SAB yöntemleri için elde edilen mod şekillerinin yüksek oranda benzerlikle aynı olduğu anlaşılır.
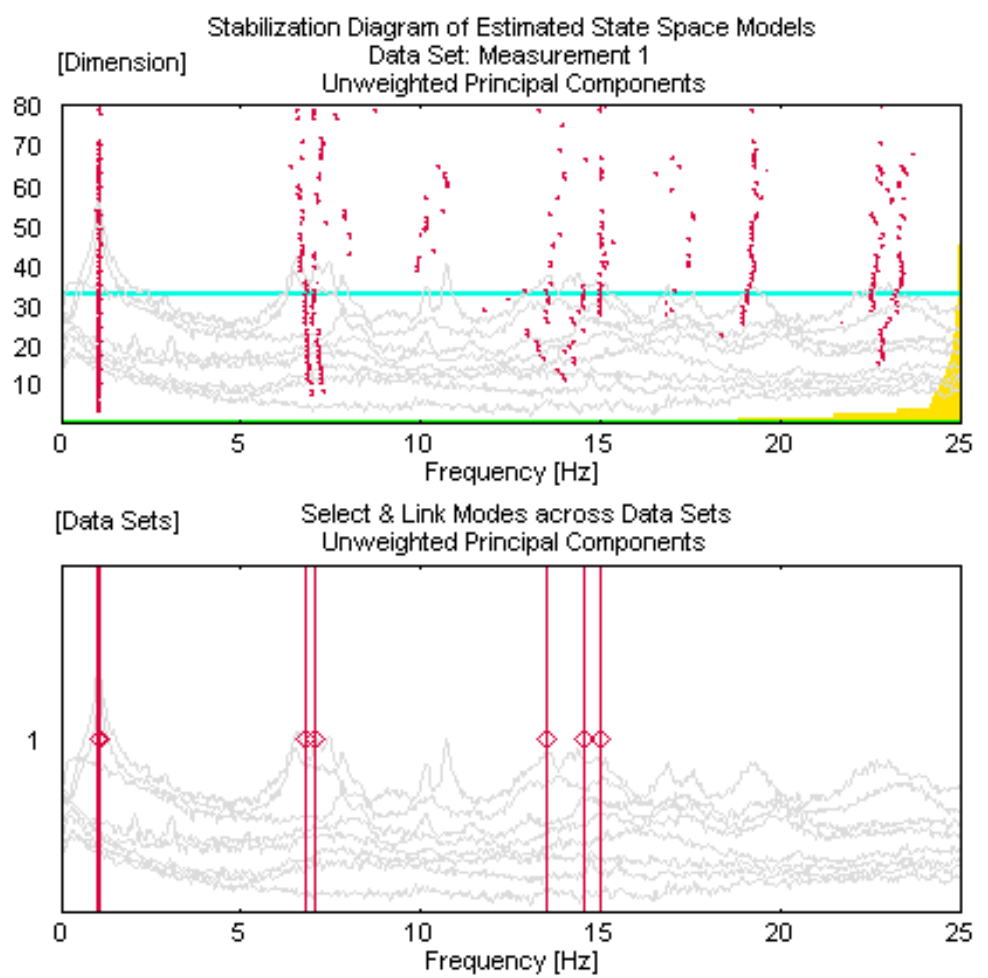

Şekil 12. Minare için elde edilen stabilizasyon ve spektral yoğunluk fonksiyonu diyagramları. 
Tablo 1. GFOA ve SAB yöntemlerine göre hesap edilen MGK değerleri.

\begin{tabular}{|c|c|c|c|c|c|c|c|}
\hline & $1.041 \mathrm{~Hz}$ & $1.084 \mathrm{~Hz}$ & $6.814 \mathrm{~Hz}$ & $7.07 \mathrm{~Hz}$ & $13.53 \mathrm{~Hz}$ & $14.54 \mathrm{~Hz}$ & $14.99 \mathrm{~Hz}$ \\
\hline $04 \mathrm{~Hz}$ & 0.9851 & 0.2366 & 0.0491 & 0.007614 & 0.02167 & 0.0006121 & 0.5435 \\
\hline $1.063 \mathrm{~Hz}$ & 0.03012 & 0.7426 & 0.003264 & 0.04741 & 0.02012 & 0.03737 & 0.0518 \\
\hline $6.401 \mathrm{~Hz}$ & 0.09694 & 0.04727 & 0.8191 & 0.03513 & 0.6073 & 0.1778 & 0.02249 \\
\hline $7.15 \mathrm{~Hz}$ & 0.004339 & 0.08113 & 0.02853 & 0.9294 & 0.1436 & 0.6681 & 0.1526 \\
\hline $13.58 \mathrm{~Hz}$ & 0.03112 & 0.002966 & 0.7827 & 0.1821 & 0.8788 & 0.008392 & 0.1634 \\
\hline $14.32 \mathrm{~Hz}$ & 0.01208 & 0.05157 & 0.1367 & 0.416 & 0.08703 & 0.9131 & 0.4886 \\
\hline $14.91 \mathrm{~Hz}$ & 0.1435 & 0.1105 & 0.1032 & 0.2981 & 0.06639 & 0.6909 & 0.7734 \\
\hline
\end{tabular}

GFOA ve SAB yöntemlerinden elde edilen doğal frekans ve sönüm oranı değerleri Tablo 2'de verilmektedir. Tablo 2 incelendiğinde; GFOA ve $\mathrm{SAB}$ yöntemlerinden elde edilen doğal frekans değerleri birbirlerine oldukça yakın olduğu, sönüm oranı değerlerinde ise farklılıkların olduğu görülmektedir. Minarenin doğal frekans değerleri
$1.04-14.99 \mathrm{~Hz}$ arasında değişmektedir. İlk yedi moda karşılık gelen sönüm oranları ise \%0.263.65 arasında değişmektedir. Sönüm oranları logaritmik azalma yöntemi ile sönüm oranların hesabına dayalı otomatik olarak program tarafindan hesaplanır.

Tablo 2. GFOA ve SAB yöntemlerinden elde edilen doğal frekans ve sönüm oranı değerleri.

\begin{tabular}{ccccc}
\hline & \multicolumn{2}{c}{ Frekans $(\mathrm{Hz})$} & Sönüm Oranı (\%) \\
\hline Mod & GFOA & SAB & GFOA & SAB \\
\hline 1 & 1.04 & 1.04 & 2.43 & 0.63 \\
2 & 1.06 & 1.08 & 0.93 & 0.90 \\
3 & 6.40 & 6.81 & 0.26 & 2.49 \\
4 & 7.15 & 7.07 & 1.03 & 2.59 \\
5 & 13.58 & 13.53 & 0.61 & 1.45 \\
6 & 14.32 & 14.54 & 1.93 & 3.65 \\
7 & 14.91 & 14.99 & - & 1.21 \\
\hline
\end{tabular}

\subsection{Onarım Öncesi ve Sonrast için Dinamik Karakteristiklerinin Karşılaştırılması}

Onarım öncesi ve sonrasında dinamik karakteristiklerde meydana gelen değişimin incelenmesi amaciyla, minarenin onarım öncesine ait deneysel dinamik karakteristikler literatürden elde edilmiştir. Bayraktar vd. (2011) tarafından, Trabzon İskenderpaşa Camii minaresinin onarım öncesi durumuna ait bir çalışma gerçekleştirilmiştir. Çalışmada, Minarenin dinamik karakteristikleri deneysel ve analitik olarak belirlenmiş, minarenin başlangıç sonlu eleman modeli oluşturulmuş ve model deneysel sonuçlara göre iyileştirilmiştir. İyileştirilen sonlu eleman modeli üzerinden minarenin dinamik davranışı belirlenmiştir.

Bayraktar vd. (2011) tarafından minare için belirlenen mod şekilleri Şekil 13'te verilmektedir. Onarım öncesi ve sonrasında elde edilen mod şekilleri incelendiğinde, her iki durumda elde edilen mod şekillerin benzer olduğu görülmektedir. Buradan onarım uygulamalarının minarenin mod şekillerini değiştirmediği anlaşılmaktadır.

Minarenin onarım öncesi ve sonrasında GFOA ve $\mathrm{SAB}$ yöntemlerine göre hesap edilen doğal frekans ve sönüm oranlarının karşılaştırılması Tablo 3'te verilmektedir. Tablo 3 incelendiğinde; onarım sonrasındaki doğal frekans değerlerinde bazı modlarda artma bazı modlarda ise azalma, sönüm oranı değerlerinde ise genellikle artma meydana geldiği görülmektedir.

Tablo 3'te görüldüğü gibi, minarede onarım uygulamasından sonra doğal frekans değerlerinde meydana gelen maksimum fark; GFOA yöntemi için \%19.01, SAB yöntemi için ise \%28.70'dir.

Minare için GFOA yöntemine göre hesaplanan sönüm oran1 değerleri literatürde verildiğinden, onarım sonrasında GFOA yöntemine göre elde 
edilen sönüm oranı değerleri Tablo 3'te verilmiş ve kıyaslanmıştır. Tablo 3'te görüldüğü gibi; onarım öncesinde sönüm oranı değerleri \%0.21$0.75 \mathrm{~Hz}$ arasında, onarım sonrasinda ise $\% 0.26$ $2.43 \mathrm{~Hz}$ arasında değişmektedir.
Burada belirtilmelidir ki; onarım sonrasında doğal frekans ve sönüm oranı değerlerinde meydana gelen değişimler, yapısal davranışında meydana gelen değişimi ifade etmektedir.

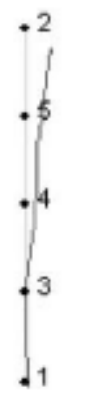

1.Mod

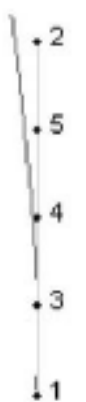

2.Mod

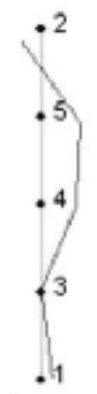

5.Mod

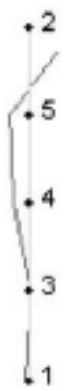

3.Mod

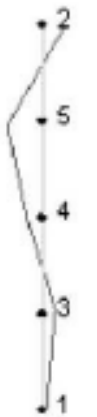

6.Mod

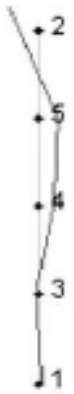

4.Mod

Şekil 13. Minarenin onarım öncesi durumuna ait mod şekilleri.

Tablo 3. Minarenin onarım öncesi ve sonrasına ait doğal frekans ve sönüm oranı değerlerinin karşılaştırılması.

\begin{tabular}{|c|c|c|c|c|c|c|c|c|}
\hline \multirow{4}{*}{ Mod } & \multicolumn{6}{|c|}{ Frekans $(\mathrm{Hz})$} & \multirow{2}{*}{\multicolumn{2}{|c|}{$\frac{\text { Sönüm Oranı }(\%)}{\text { GFOA }}$}} \\
\hline & \multicolumn{3}{|c|}{ GFOA } & \multicolumn{3}{|c|}{ SAB } & & \\
\hline & Onarım & Fark & Onarım & Onarım & Fark & Onarım & Onarım & Onarım \\
\hline & Öncesi & $(\%)$ & Sonras1 & Öncesi & $(\%)$ & Sonrası & Öncesi & Sonras1 \\
\hline 1 & 1.16 & -11.53 & 1.04 & 1.29 & -24.04 & 1.04 & 0.75 & 2.43 \\
\hline 2 & 1.24 & -16.98 & 1.06 & 1.39 & -28.70 & 1.08 & 0.33 & 0.93 \\
\hline 3 & 6.30 & +1.58 & 6.40 & 5.58 & +22.04 & 6.81 & 0.28 & 0.26 \\
\hline 4 & 6.35 & +12.60 & 7.15 & 5.70 & +24.04 & 7.07 & 0.42 & 1.03 \\
\hline 5 & 11.41 & +19.01 & 13.58 & 11.39 & +18.79 & 13.53 & 0.74 & 0.61 \\
\hline 6 & 15.02 & -4.89 & 14.32 & 14.00 & +3.86 & 14.54 & 1.04 & 1.93 \\
\hline 7 & 15.43 & -3.49 & 14.91 & 14.10 & +6.31 & 14.99 & 0.21 & 1.21 \\
\hline
\end{tabular}

\section{Sonuçlar}

$\mathrm{Bu}$ çalışmada; Trabzon İskenderpaşa Camii Minaresinin onarım sonrasındaki dinamik karakteristikleri Çevresel Titreşim Yöntemi ile elde edilmiş, elde edilen sonuçlar literatürde var olan onarım öncesi sonuçlar ile karşılaştırılmıştır.
Elde edilen sonuçlar ve öneriler aşağıda sunulmuştur.

- Minarenin onarım sonrasındaki çevresel titreşim testinden toplanan sinyallerin GFOA ve $\mathrm{SAB}$ yöntemlerine göre ayrıştırılması sonucu belirlenen mod şekilleri birbiriyle uyumlu, hesaplanan doğal frekans değerleri ise birbirine oldukça yakındır. 
- Minarenin onarım sonrasındaki doğal frekans değerleri 1.04-14.99Hz arasında, sönüm oran1 değerleri ise $\% 0.26-3.65 \mathrm{~Hz}$ arasında değişmektedir.

- Onarım öncesi ve sonrasında elde edilen mod şekillerinin benzerdir.

- Onarım sonrasındaki doğal frekans değerlerinde, bazı modlar için artma bazı modlar için ise azalma elde edilmiştir. Sönüm oranı değerleri onarım sonrasında genellikle artmıştır.

- Onarım uygulamalarından sonra doğal frekans değerlerinde maksimum \%28.70'lik bir değişim elde edilmiştir. Sönüm oranı değerleri ise oldukça artmıştır.

- Onarım sonrasındaki doğal frekans ve sönüm oranı değerlerinde meydana gelen farklılıklara; minare üzerinde gerçekleştirilen onarım uygulamalarının ya da minare yakınında gerçekleştirilen zemin kazısı nedeniyle mesnetlenme koşullarında meydana gelen değişimlerin neden olabileceği düşünülmektedir.

Yukarıda elde edilen sonuçlar göstermiştir ki, minarenin onarım uygulamalarıyla birlikte dinamik karakteristikleri değişmektedir. $\mathrm{Bu}$ değişimin doğrudan yapının dinamik davranışına etki edeceği açıktır. Bu nedenle, tarihi yapılar üzerinde gerçekleştirilen onarım/güçlendirme ya da restorasyon müdahalelerinin öncesi ve sonrasında dinamik karakteristiklerin belirlenmesi oldukça önemli olmaktadır. Bu gibi kültür mirası yapıları gelecek nesillere özgün halini koruyarak aktarmak, olası bir dinamik etkide oluşacak can ve mal kaybını azaltmak ya da engellemek için deneysel yöntemler ile yapı sağlığının periyodik olarak izlenmesi oldukça önem arz etmektedir. Ayrıca yapının dinamik davranışının elde edilmesinde kullanılacak sonlu eleman modelinin deneysel ölçüm sonuçlarına göre iyileştirilmesi, iyileştirilen model üzerinden yap1 dinamik davranışının elde edilmesi doğru sonuçların elde edilmesinde faydalı olacaktır.

$\mathrm{Bu}$ çalışmadan elde edilen dinamik karakteristikler, Trabzon İskenderpaşa Camii Minaresinin onarım sonrasındaki dinamik davranışının elde edilmesinde kullanılacak sonlu eleman modelinin iyileştirilmesinde kullanılabilir. $\mathrm{Bu}$ sayede yapının mevcut halini temsil eden sonlu eleman modeli oluşturulabilir ve dinamik davranışı elde edilebilir.

\section{Teşekkür}

Yazar, Trabzon İskenderpaşa Camii Minaresinin onarım uygulamalarıyla ilgili aşamaların öğrenilmesinde büyük katkıları olan Erzurum Vakıflar Bölge Müdürü İsmet ÇALIK'a teşekkür eder. Yazar ayrica, minarenin deneysel ölçümlerinin alınması sırasındaki yardımlarından dolayı Arş. Gör. Ali Fuat GENÇ’e ve Arş. Gör. Fatih Yesevi OKUR'a, katkılarından dolayı Prof. Dr. Ahmet Can ALTUNIŞIK'a teşekkür eder.

\section{Kaynaklar}

Allemang, R.J., 2003. The Modal Assurance Criterion: Twenty Years of Use and Abuse, Sound and Vibration, 37, 8, 14-23.

Altunışık, A.C., 2010. Karayolu Köprülerinin Yapısal Davranışlarının Analitik ve Deneysel Yöntemleriyle Belirlenmesi, Doktora Tezi, KTÜ Fen Bilimleri Enstitüsü, Trabzon.

Altunışık, A.C., Adanur, S., Genç, A.F., Günaydın, M. ve Okur, F.Y., 2016. NonDestructive Testing of an Ancient Masonry Bastion, Journal of Cultural Heritage, 22, 1049-1054.

Atamturktur, S. ve A. Laman, J., 2012. Finite Element Model Correlation and Calibration of Historic Masonry Monuments: Review, The Structural Design of Tall and Special Buildings, 21, 96-113.

Bayraktar, A., Altunışık, A.C., Sevim, B. ve Türker, T., 2011. Seismic Response of a Historical Masonry Minaret using a Finite Element Model Updated with Operational Modal Testing, Journal of Vibration and Control, 17, 129-149.

Bendat, J.S. ve Piersol, A.G., 2004. Random Data: Analysis and Measurement Procedures, 3th Edition, John Wiley and Sons, USA.

Brencich, A. ve Sabia, D., 2008. Experimental Identification of a Multi-Span Masonry Bridge: The Tanaro Bridge, Constr. Build. Mater., 22, 2087-2099.

Brincker, R., Ventura, C.E. ve Andersen, P., 2003. Why Output-Only Modal Testing is a Desirable Tool for a Wide Range of Practical Applications, Proceedings of 21st 
International Modal Analysis Conference on Structural Dynamics, Kissimmee, Orlando, USA.

Çalık, İ., 2017. Tarihi Cami ve Minarelerin Deneysel Dinamik Karakteristiklerinin Belirlenmesi ve Restorasyon Etkilerinin Değerlendirilmesi, Doktora Tezi, KTÜ Fen Bilimleri Enstitüsü, Trabzon.

Doğangun, A. ve Sezen, H., 2012. Seismic Vulnerability and Preservation of Historical Masonry Monumental Structures, Eng. Struct., 3, 83-95.

Felber, A. J.,1993. Development of Hybrid Bridge Evaluation System, PhD Thesis, University of British Columbia, Vancouver, Canada.

Gentile, C. ve Saisi, A., 2007. Ambient Vibration Testing of Historic Masonry Tower for Structural Identification and Damage Assessment, Constr. Build. Mater., 21, 1311-1321.

Günaydın, M., 2016. Onarılmış ve Lifli Polimer Kompozit Malzemelerle Güçlendirilmiş Betonarme Binaların Dinamik Davranışlarının Deneysel ve Analitik Yöntemlerle İncelenmesi, Doktora Tezi, KTÜ Fen Bilimleri Enstitüsü, Trabzon.

Ivorra, S. ve Pallares F.J., 2007. A Masonry BellTower Assessment by Modal Testing. International Operational Modal Analysis Conference Copenhagen Denmark, s. 1-7.

Livaoğlu, R., Baştürk, M.H. ve Serhatoğlu, C., 2015. Dynamic Characteristics of Minarets of Hoca Tabip Mosque, 6th Iomac Internation Operational Modal Analysis Conference, 10-12 May, Gijon-Spain.

Lourenço, P.B. ve Ramos, L.F., 2011. Dynamic Identification and Monitoring of Cultural Heritage Buildings, WCCE-ECCE-TCCE Joint Conference 2, Seismic Protection of Cultural Heritage, s. 55-78.

OMA. 2006. Operational Modal Analysis, Release 4.0, Structural Vibration Solution A/S, Denmark.

Peeters, B. ve Roeck, G.D., 2000. Reference Based Stochastic Subspace Identification in Civil Engineering, Inverse Problems in Civil Engineering, 8, 47-74.
Peeters, B., 2000. System Identification and Damage Detection in Civil Engineering, Doktora Tezi, K.U, Leuven, Belgium.

PULSE, 2006. Analyzers and Solutions, Release 11.2. Bruel and Kjaer, Sound and Vibration Measurement A/S, Denmark.

Rainieri, C., Fabbrocino, G., Cosenza, E., and Manfredi, G. 2007. Implementation of OMA Procedures using Labview: Theory andApplication, 2nd International Operational Modal Analysis Conference, 30 April-2 May, Copenhagen, Denmark, 1-13.

Ramos, L.F., Marques, L., Lourenço, P.B., De Roeck, G., Campos-Costa, A. ve Roque, J., 2010. Monitoring Historical Masonry Structures with Operational Modal Analysis: Two Case Studies, Mechanical Systems and Signal Processing, 24, 12911305.

Saisi, A., Gentile, C. ve Guidobaldi, M., 2015. Post-Earthquake Continuous Dynamic Monitoring of the Gabbia Tower in Mantua, Italy, Constr. Build. Mater., 81, 101-112.

Sevim, B., 2010. Kemer Barajların Dinamik Davranışlarının Sonlu Eleman ve Deneysel Modal Analiz Yöntemleriyle Belirlenmesi, Doktora Tezi, KTÜ Fen Bilimleri Enstitüsü, Trabzon.

Torres, W., Almazan, J.L., Sandoval, C., ve Boroschek, R., 2017. Operational Modal Analysis and FE Model Updating of the Metropolitan Cathedral of Santiago, Chile, Engineering Structures, 143, 169-188.

Tuluk, Ö.İ., 2007. Trabzon İskender Paşa Camii: Fiziksel Gelişim Süreci Üzerine Bir Değerlendirme, Uluslararas1 Karadeniz İncelemeleri Dergisi, 3, 9-16.

Türker, T., 2014. Structural evaluation of Aspendos (Belkis) Masonry Bridge, Structural Engineering and Mechanics, 50, 419-439.

Yu, D.J. ve Ren, W.X., 2005. EMD- Based Stochastic Subspace Identification of Structures from Operational Vibration Measurements, Engineering Structures, 27, 1741-1751. 
Zhang, L., Brincker, R. ve Andersen, P., 2002. An Overview of Operational Modal Analysis: Major Development and Issues, B\&K Technical Paper, 152-161.

URL-1, http://www.iha.com.tr/haber-firtinaminareleri-yikti-267638/. 06 Ocak 2018.
URL-2, http://www.iha.com.tr/haber-ruzgarminareleri-yikti-109116/. 06 Ocak 2018.

URL-3, http://www.trabzon.bel.tr/haberdetay.aspx?id=7019. 06 Ocak 2018.

URL-4, http://www.milliyet.com.tr/meydan-parki2-etap-duzenleme-calismalari-trabzonyerelhaber-206616/.06 Ocak 2018. 